\title{
PENYESUAIAN DIRI PADA ORANG DENGAN HIV DAN AIDS (ODHA) DITINJAU DARI DUKUNGAN SOSIAL
}

\author{
Anna Dian Savitri ${ }^{1}$, Purwaningtyastuti ${ }^{1}$ \\ 1Prodi Psikologi, Fakultas Psikologi, Universitas Semarang \\ dsavie@usm.ac.id
}

\begin{abstract}
Due to stigma and discrimination in living, living not all will open its status to others. Living will open its status to others with many considerations, namely of them to reduce the burden of being perceived, to gain support social and economically support as well as as a form of concern on the community. This research aims to understand the relationship between social support and the adjustment of themselves on living who underwent the treatment of antiretroviral therapy. Methods used in research is quantitative methods. Data collection method used adjustment scale and scale social support. The subject of study is 33 ODHA that is undergoing treatment ARV at the hospital "X" Semarang. A method of the sample use the study population. Analysis techniques the data used was a product moment. The correlation analysis product moment of pearson of 0,130 with the significance $\quad 0,471(p>0,05)$. This value shows that there is no a positive relationship between the social support variable adjustment themselves, so hypothesis in this research rejected.
\end{abstract}

Keywords: adjustment, social support, ODHA

\begin{abstract}
Abstrak. Akibat stigma dan diskriminasi pada ODHA, tidak semua ODHA mau membuka statusnya kepada orang lain. ODHA mau membuka statusnya kepada orang lain dengan berbagai pertimbangan, yaitu di antaranya untuk mengurangi beban yang dirasakan, untuk mendapatkan dukungan sosial maupun dukungan secara ekonomi serta sebagai wujud kepedulian terhadap masyarakat. Penelitian ini bertujuan untuk mengetahui hubungan antara dukungan sosial dan penyesuaian diri pada ODHA yang menjalani pengobatan ARV. Metode yang digunakan dalam penelitian ini adalah metode kuantitatif. Metode pengumpulan data menggunakan skala penyesuaian diri dan skala dukungan sosial. Subjek penelitian adalah 33 ODHA yang sedang menjalani pengobatan ARV di RS "X" Semarang. Metode pengambilan sampel menggunakan studi populasi. Teknik analisis data yang digunakan adalah korelasi product moment. Hasil analisis korelasi product moment dari Pearson sebesar 0,130 dengan angka signifikansi 0,471 ( $p>0,05)$. Nilai ini menunjukkan bahwa tidak terdapat hubungan positif antara variabel dukungan sosial dengan variabel penyesuaian diri, sehingga hipotesis dalam penelitian ini ditolak.
\end{abstract}

Kata kunci: penyesuaian diri, dukungan sosial,ODHA

\section{Pendahuluan}

HIV (Human Immuno Defeciency Syndrom) adalah virus yang menginfeksi manusia dengan menyerang sistem imun atau sistem kekebalan tubuh manusia sehingga tidak mampu melindungi diri dari serangan penyakit lain Menurut laporan WHO (World Health Organization) pada akhir 2009 sekitar 33.3 juta orang hidup dengan HIV. Pada tahun yang sama, sekitar 2,6 juta orang dengan kasus infeksi baru HIV, dan 1,8 juta meninggal karena AIDS termasuk 


\section{Philantrophy Journal of Psychology \\ 2017, Vol 1 Nomor 1 17-25}

260.000 anak-anak. Dari semua ODHA, 68\% diantaranya berada di sub-sahara Afrika di mana terdapat sekitar 10,7 juta orang membutuhkan ART (Antiretroviral Teraphi).

Laporan monitoring VCT sampai Juni 2011 menyebutkan jumlah kasus HIV positif di Indonesia kumulatif sebanyak 66.693 kasus. Secara kumulatif kasus HIV terbanyak dilaporkan dari Provinsi DKI Jakarta, yaitu sebanyak 17.130 kasus, Jawa Timur sebanyak 8.469 kasus, Papua sebanyak 5.473 kasus, Jawa Barat sebanyak 4.974, Sumatera Utara sebanyak 4.382 kasus, Bali sebanyak 3.649 kasus, dan Jawa Tengah sebanyak 3.059 kasus (Kementerian Kesehatan, 2011), dari april sampai dengan Juni 2011 jumlah kasus AIDS yang baru dilaporkan adalah 2.001 kasus dari 59 kabupaten/kota di 19 provinsi. Kasus AIDS terbanyak dilaporkan dari DKI Jakarta, Jawa Timur, Jawa Barat, Papua, Bali, Jawa Tengah, Kalimantan Barat, Sulawesi Selatan, Daerah Istimewa Yogyakarta, dan Sulawesi Utara.

Dari data yang dikeluarkan oleh Dinas Kesehatan Provinsi Sulawesi Selatan, kasus HIV\&AIDS dari tahun 2005 hingga 2011 di Provinsi Sulawesi Selatan yaitu 5.156 kasus. Sementara data dari Dinas Kesehatan Kota Makassar menyebutkan bahwa jumlah kasus HIV\&AIDS di Kota Makassar hingga September 2011 sebanyak 4.219 kasus.

Berdasarkan data yang diperoleh dari petugas kesehatan Puskesmas Jumpandang Baru, hingga Februari 2012 ODHA yang aktif mengikuti terapi ARV adalah 103 orang, yang terdiri dari 75 pria dan 28 wanita.

Masalah yang timbul pada orang pengidap HIV/AIDS bukan hanya dari infeksi virus, tetapi ada juga dampak-dampak sosial yang terjadi, misalnya dijauhi teman, keluarga, maupun dari masyarakat luas. Ketika individu dinyatakan terinfeksi HIV, sebagian besar menunjukkan perubahan karakter psikososial yaitu: hidup dalam stres, depresi, merasa kurangnya dukungan sosial, dan perubahan.

AIDS (Acquired Immuno Deficiency Syndrome) adalah sekumpulan gejala dan infeksi yang timbul karena rusaknya sistem kekebalan tubuh akibat infeksi virus HIV (Human Immunodeficiency Virus). Virus tersebut mengakibatkan penurunan dan kerusakan sistem kekebalan tubuh, sehingga orang yang terinfeksi akan menjadi rentan terhadap berbagai macam penyakit. Penyakit ini menjadi pandemi di seluruh dunia. Hampir semua negara menyumbangkan angka kejadian penyakit HIV/AIDS (Kementerian Kesehatan, 2013).

Direktorat Jenderal Pengendalian Penyakit dan Penyehatan Lingkungan Kementerian Kesehatan (Ditjen PP\&PL) melaporkan bahwa sejak tahun 1987 sampai dengan 2013, penderita yang terinfeksi HIV sebanyak 127.416 orang, kasus AIDS yang ditemukan sebanyak 52.348 penderita, dan jumlah kematian akibat HIV/AIDS sebanyak 9.587 penderita. Dari banyak kasus yang ditemukan di Indonesia, kejadian tertinggi infeksi HIV terdapat di Provinsi DKI Jakarta, yaitu sebanyak 28.790 penderita, sedangkan kasus AIDS tertinggi terdapat di Provinsi Papua, yaitu sebanyak 10.116 penderita (Kementerian Kesehatan, 2013). 


\section{Philantrophy Journal of Psychology}

2017, Vol 1 Nomor 1 17-25

Provinsi Jawa Tengah menduduki peringkat ke-7 nasional setelah DKI Jakarta, Jawa Timur, Papua, Jawa Barat, Bali, dan Sumatra Utara. Jumlah penderita HIV di Jawa Tengah yang ditemukan sampai dengan tahun 2013 sebanyak 6.963 penderita, sedangkan jumlah penderita AIDS sebanyak 1.042 dengan jumlah kematian sebanyak 1.111 orang (Kementerian Kesehatan, 2013).

Bahkan berdasarkan hasil wawancara yang dilakukan pada 11 Agustus 2015 dengan Konselor yang mendampingi ODHA, masih terdapat ODHA yang mengalami hambatan dalam menyesuaikan dirinya dengan lingkungan sekitar, meskipun dukungan dari keluarga dan teman sesama ODHA selalu diperoleh.

Tingginya pertumbuhan HIV/AIDS di Indonesia dipengaruhi oleh 3 hal, yaitu: meningkatnya pengguna narkoba suntik, maraknya seks bebas, dan kelahiran bayi oleh ibu yang terinfeksi HIV (Kementerian Kesehatan, 2013). Penyakit HIV/AIDS menimbulkan masalah yang cukup luas, baik pada orang yang terinfeksi HIV/AIDS (ODHA) maupun orang yang hidup dengan penderita HIV/AIDS (ODHA).

Masalah yang muncul adalah masalah fisik, sosial, dan emosional. Masalah fisik terjadi akibat dari penurunan daya tahan tubuh secara progresif yang mengakibatkan ODHA rentan terhadap berbagai macam penyakit terutama penyakit infeksi dan keganasan. Penyakit infeksi yang sering muncul pada penderita HIV/AIDS adalah tuberkulosis paru (TB paru), radang pada paru-paru (pneumonia), kelainan kulit berupa herpes simplex atau zoster, diare kronik, dan infeksi pada hati (hepatitis). Penyakit keganasan diantaranya adalah kanker lapisan pembuluh darah limfatik (sarcoma kaposi) dan kanker sistem kekebalan tubuh/limfoma (Nursalam dan Kurniawati, 2007). Masalah sosial dan emosional pada ODHA muncul akibat stigma negatif dari masyarakat. Stigma tersebut akhirnya mengakibatkan perlakuan diskriminatif terhadap mereka. Stigma dan diskriminasi terjadi karena adanya anggapan bahwa penyakit HIV/AIDS selalu berujung pada kematian. Penyakit ini sering diasosiasikan dengan perilaku atau kebiasaan buruk yang dianggap tidak sesuai dan bertentangan dengan norma positif dalam masyarakat, persepsi masyarakat bahwa ODHA dengan sengaja menularkan penyakitnya, serta kurangnya pengetahuan yang benar tentang cara penularannya (Kementerian Kesehatan, 2012).

Akibat stigma dan diskriminasi pada ODHA, akhirnya tidak semua ODHA mau membuka statusnya kepada orang lain. ODHA mau membuka statusnya kepada orang lain dengan berbagai pertimbangan, yaitu diantaranya untuk mengurangi beban yang dirasakan, untuk mendapatkan dukungan sosial maupun dukungan secara ekonomi serta sebagai wujud kepedulian terhadap masyarakat (Sukmandari, 2012). Hasil riset kesehatan dasar (Riskesdas) yang dilakukan oleh Kementerian Kesehatan tahun 2010, menemukan data bahwa sikap diskriminatif terhadap anggota keluarga yang terinfeksi HIV cukup tinggi. Sebanyak 21,7\% 


\section{Philantrophy Journal of Psychology \\ 2017, Vol 1 Nomor 1 17-25}

masih merahasiakan apabila ada anggota yang terinfeksi HIV/AIDS, dan terdapat 7,1\% penduduk yang bersifat mengucilkan ODHA (Kementerian Kesehatan, 2010).

Dampak stigma dan diskriminasi secara sosial yang dialami ODHA berupa pengucilan, pengusiran, pemutusan hubungan kerja (PHK), kekerasan, kehilangan kesempatan akses pelayanan kesehatan, serta berkurangnya dukungan sosial. Sedangkan dampak stigma secara emosional yang paling sering ditemukan adalah masalah depresi.

Dukungan sosial merupakan salah satu bentuk kegiatan untuk mengurangi hambatan penyesuaian diri dengan memberikan perhatian, kenyamanan, dan meningkatkan kepercayaan diri seseorang (Glanz et al., 2008). Dukungan sosial yang diberikan dapat berupa informasi atau nasihat verbal atau nonverbal, bantuan nyata, atau tindakan yang diberikan oleh keakraban sosial. Selain itu, dukungan sosial bisa didapat karena kehadiran mereka mempunyai manfaat secara emosional serta memberikan efek perilaku bagi pihak penerima (Gottlieb, 1983). Sumber dukungan sosial dapat diperoleh dari keluarga, pasangan hidup, teman atau sahabat, tenaga kesehatan maupun jaringan sosial (Sarafino, 1990). Dukungan sosial pada ODHA dapat memengaruhi kondisi fisik, mental, sosial, dan perilaku sehat serta kualitas hidup (Robert dan Rebbeca 2004). Dampak lain dukungan sosial adalah dapat memengaruhi kepatuhan ODHA dalam menjalani pengobatan ARV (Edwards, 2006) dan mampu membantu seseorang mengurangi masalah kesehatan yang lebih serius (Tailor, 2003). Dampak lain dukungan sosial adalah dapat menurunkan stres dan angka kematian, terutama pada penyakit cardiovascular, neuroendokrin dan auto immune disease (House, 1987).

Penyesuaian diri adalah usaha manusia untuk mencapai harmoni pada diri sendiri dan pada lingkungan, sehingga rasa permusuhan, dengki, iri hati, prasangka, depresi, kemarahan dan emosi negatif sebagai respon pribadi yang tidak sesuai dan kurang efisien bisa dikikis habis (Kartono, 2000).

Fahmi (1997) mengatakan bahwa penyesuaian diri adalah proses dinamis terus-menerus yang bertujuan untuk mengubah perilaku guna mendapatkan hubungan yang lebih serasi antara diri dan lingkungannya. Manusia dituntut untuk menyesuaikan diri dengan lingkungan sosial, kejiwaan, dan alam sekitarnya. Kehidupan ini sendiri secara alamiah juga mendorong manusia untuk terus-menerus menyesuaikan diri. Davidoff (1991) mendefinisikan penyesuaian diri sebagai proses usaha untuk mempertemukan tuntutan diri sendiri dengan lingkungan. Penyesuaian diri dengan diri sendiri adalah bagaimana individu mempersepsi dirinya sendiri, potensi-potensi yang dimiliki, dan tingkat kepuasan akan hasil atau pengalaman yang diperoleh. Penyesuaian diri dengan lingkungan adalah bagaimana individu mempersepsi dan bersikap terhadap realitas yang ada. Individu yang mempunyai penyesuaian diri yang baik dapat mengendalikan perasaan cemas, khawatir, dan marah apabila mendapat suatu tekanan dari 


\section{Philantrophy Journal of Psychology}

2017, Vol 1 Nomor 1 17-25

lingkungan. Hal ini disebabkan oleh adanya dorongan untuk mengatasi hambatan-hambatan dalam mengaktualisasikan diri di lingkungan.

Gerungan (1996) menyatakan bahwa penyesuaian diri berarti mengubah diri sesuai dengan keadaan lingkungan (autoplastis) dan mengubah lingkungan sesuai dengan keinginan diri (alloplastis). Jadi penyesuaian diri dapat bersifat pasif yaitu kegiatan individu ditentukan oleh lingkungan dan dapat bersifat aktif yaitu kegiatan individu memengaruhi lingkungan. Dikarenakan lingkungan dan keinginan individu yang selau berubah, maka penyesuaian diri sifatnya selalu dinamis antara autoplastis dan alloplastis. Penyesuaian diri merupakan proses yang mencakup respon mental dan tingkah laku, yaitu individu berusaha keras agar mampu mengatasi konflik dan frustrasi karena terhambatnya kebutuhan dalam dirinya, sehingga tercapai keselarasan dan keharmonisan antara tuntutan dalam diri dan tuntutan dari lingkungan (Schneiders dalam Pramadi, 1996). Penyesuaian diri dapat diperoleh melalui proses belajar memahami, mengerti, dan berusaha melakukan apa yang diinginkan individu maupun lingkungannya. Individu yang mampu menyesuaikan diri dengan baik akan mampu mencari sisi positif dari hal baru yang dimilikinya, kreatif dalam mengolah kondisi serta mampu mngendalikan diri, sikap, dan perilakunya. Adanya hal-hal tersebut membuat individu akan lebih mudah diterima oleh lingkungan.

Hurlock (1991) mengatakan bahwa penyesuaian sosial berarti keberhasilan seseorang untuk menyesuaikan diri terhadap orang lain pada umumnya dan terhadap kelompok pada khususnya. Eysenck dkk. (1992) mendefinisikan penyesuaian sosial sebagai suatu proses untuk mencapai suatu keseimbangan sosial dengan lingkungan dan sebagai proses belajar, yaitu belajar memahami, mengerti, dan berusaha untuk melakukan apa yang harus dilakukan dan yang diinginkan oleh individu maupun lingkungan sosialnya Jersild (dalam Listyawati, 2002) mengemukakan aspek-aspek penyesuaian diri, yaitu:

a. Kesadaran Selektif

Penyesuaian yang sehat membutuhkan kemampuan individu untuk melaksanakan seleksi terhadap berbagai tekanan yang ada, untuk direspon secara tepat dengan tidak membahayakan diri individu tersebut. Kemampuan melakukan seleksi tergantung pada pengalaman dari hasil belajar.

b. Kemampuan Toleransi

Merupakan kemampuan individu untuk menerima kehadiran individu lain dan menganggap orang lain sebagaimana adanya, mampu menerima nilai-nilai hidup serta kode-kode moral dan mampu mengembangkan hidupnya dengan baik tanpa mengabaikan kepentingan lingkungan.

c. Otonomi 


\section{Philantrophy Journal of Psychology \\ 2017, Vol 1 Nomor 1 17-25}

Otonomi individu meliputi tiga aspek, yaitu otonomi emosi, kemampuan melakukan hubungan emosional secara bebas dengan orang lain, otonomi perilaku, yaitu kemampuan atau kecakapan pengambilan keputusan secara bebas dan otonomi nilai, yaitu kemampuan memaknai seperangkat prinsip benar dan salah, serta apa yang penting dan tidak penting. Penyesuaian sosial dianggap berhasil ketika individu mampu menyelaraskan ketiga aspek tersebut dalam kehidupan sosial.

d. Integritas Pribadi

Individu yang mempunyai penyesuaian sosial yang sehat tidak akan merasa takut atau cemas jika menghadapi hal-hal yang baru. Selain itu juga tidak akan merasa panik jika suatu saat menghadapi kesulitan atau hambatan dalam mencapai tujuan hidupnya.

Dukungan sosial sangat diperlukan oleh siapa saja dalam berhubungan dengan orang lain demi melangsungkan hidupnya di tengah-tengah masyarakat. Rook (dalam Smet, 1994) mengatakan bahwa dukungan sosial merupakan salah satu fungsi dari ikatan sosial dan ikatanikatan sosial tersebut menggambarkan tingkat kualitas umum dari hubungan interpersonal. Ikatan dan persahabatan dengan orang lain dianggap sebagai aspek yang memberikan kepuasan secara emosional dalam kehidupan individu. Saat seseorang didukung oleh lingkungan maka segalanya akan terasa lebih mudah. Dukungan sosial menunjukkan pada hubungan interpersonal yang melindungi individu terhadap konsekuensi negatif dari stres. Dukungan sosial yang diterima dapat membuat individu merasa tenang, diperhatikan, dicintai, timbul rasa percaya diri, dan kompeten.

Menurut Cobb (dalam Shinta, 1995) dukungan sosial adalah pemberian informasi baik secara verbal maupun nonverbal, pemberian bantuan tingkah laku atau materi yang didapat dari hubungan sosial yang akrab atau hanya disimpulkan dari keberadaan mereka yang membuat individu merasa diperhatikan, bernilai, dan dicintai, sehingga dapat menguntungkan bagi kesejahteraan individu yang menerima. Hal senada diungkap oleh Gottlieb dalam Smet (1994) yang menyatakan bahwa dukungan sosial terdiri dari informasi atau nasihat verbal dan nonverbal, bantuan yang nyata atau tindakan yang diberikan oleh orang lain atau didapat karena hubungan mereka dengan lingkungan dan mempunyai manfaat emosional atau efek perilaku bagi dirinya. Dalam hal ini orang yang merasa memperoleh dukungan sosial secara emosional merasa lega karena diperhatikan, mendapat saran atau kesan yang menyenangkan pada dirinya, agar mereka dapat mencari jalan keluar untuk memecahkan masalahnya.

Sarafino (1998) mengatakan bahwa dukungan sosial adalah kenyamanan, perhatian, penghargaan atau bantuan yang diperoleh individu dari orang lain, di mana orang lain di sini dapat diartikan sebagai individu perorangan atau kelompok. Hal tersebut menunjukkan bahwa segala sesuatu yang ada di lingkungan menjadi dukungan sosial atau tidak, tergantung pada sejauh mana individu merasakan hal tersebut sebagai dukungan sosial. 
Dukungan sosial didefinisikan oleh House (dalam Smet, 1994) sebagai transaksi interpersonal yang melibatkan satu atau lebih aspek-aspek yang terdiri dari informasi, perhatian emosional, penilaian dan bantuan instrumental. Tersedianya dukungan sosial akan membuat individu merasa dicintai, diperhatikan, dihargai, dan menjadi bagian dalam kelompok.

Menurut Effendi dan Tjahjono (1999) dukungan sosial merupakan transaksi interpersonal yang ditujukan dengan memberikan bantuan kepada individu lain dan bantuan itu diperoleh dari orang yang berarti bagi individu yang bersangkutan. Dukungan sosial berperan penting dalam memelihara keadaan psikologis individu yang mengalami tekanan, sehingga menimbulkan pengaruh positif yang dapat mengurangi gangguan psikologis. Selain itu dukungan sosial dapat dijadikan pelindung untuk melawan perubahan peristiwa kehidupan yang berpotensi penuh dengan stres, sehingga dapat meningkatkan kesejahteraan psikologis karena adanya perhatian dan pengertian akan menimbulkan perasaan memiliki, meningkatkan harga diri, dan kejelasan identitas diri, serta memiliki perasaan positif mengenai diri sendiri.

Berdasarkan uraian teori yang telah dikemukakan sebelumnya, maka hipotesis dalam penelitian ini adalah ada hubungan positif antara dukungan sosial dengan penyesuaian diri pada ODHA yang menjalani pengobatan ARV. Semakin positif dukungan sosial yang diterima maka semakin positif penyesuaian dirinya, begitu pula sebaliknya.

\section{Metode}

Penelitian ini menggunakan metode kuantitatif dengan subyek 33 ODHA yang menjalani terapi ARV. Teknik Pengumpulan Data menggunakan skala penyesuaian diri dan skala dukungan sosial. Metode analisis data menggunakan korelasi product moment.

\section{Hasil dan Pembahasan}

Nilai koefisien korelasi berdasarkan analisis yang dilakukan melalui teknik korelasi product moment dari Pearson adalah sebesar 0,130 dengan angka signifikansi 0,471 ( $p>0,05$ ). Nilai ini menunjukkan bahwa tidak terdapat hubungan positif antara variabel dukungan sosial dengan variabel penyesuaian diri. Angka signifikansi pada penelitian ini memiliki nilai yang lebih besar dari 0,05 dan sesuai dengan kaidah yang telah ditentukan bahwa jika angka signifikansi hasil penelitian > dari 0,05 maka hipotesis penelitian ditolak. Hal tersebut menunjukkan bahwa dukungan sosial yang telah diterima subjek ternyata belum dapat membantu subjek dalam melakukan sosialisasi. Penelitian yang dilakukan oleh Tuapattinaja (2004) bahwa dukungan sosial yang diterima ODHA belum mampu meredakan kecemasan atau 
kondisi stres yang muncul terkait dengan sakit yang diidapnya, sehingga ODHA hanya menjadi lebih tenang dan tetap mengalami kesulitan dalam penyesuaian diri. ODHA sebenarnya tidak hanya mengalami tekanan akibat adanya virus HIV yang menyerang sistem kekebalan tubuh saja, tetapi ODHA juga dihadapkan pada stigma dan diskriminasi. Sesuai dengan yang diungkapkan oleh Smetzer dan Bare (2002) bahwa ODHA sering mendapat stigma akibat dari virus yang menginfeksinya. ODHA sering disebut sebagai orang yang mengidap penyimpangan seksual atau gay, wanita nakal, dan salah pergaulan. Melalui stigma tersebut, ODHA kemudian dikucilkan dan tanpa disadari bahwa tindakan tersebut sebenarnya telah memengaruhi kondisi psikologis ODHA. Hal ini mengantarkan ODHA pada kondisi stres, depresi, putus asa, dan menutup diri. ODHA akan memilih untuk merahasiakan status kesehatannya dari keluarga, teman maupun kerabat dekatnya, sehingga ODHA pun tidak mampu mendapatkan dukungan yang seharusnya diperoleh (Gunung, Sumantera, Sawitri, \& Wirawan, 2002). ODHA se benarnya membutuhkan dukungan, bukan dikucilkan agar harapan hidup ODHA menjadi lebih panjang. Sarafino (2011) mengungkapkan bahwa dengan adanya dukungan sosial maka akan tercipta lingkungan kondusif yang mampu memberikan motivasi maupun memberikan wawasan baru bagi ODHA dalam menghadapi kehidupannya. Dukungan sosial ini dapat meminimalkan tekanan psikososial yang dirasakan ODHA, sehingga ODHA dapat memiliki gaya hidup yang lebih baik dan dapat memberikan respon yang lebih positif terhadap lingkungan sosialnya. Selain itu, dengan adanya dukungan sosial ini maka ODHA akan merasa dihargai, dicintai, dan merasa menjadi bagian dari masyarakat, sehingga ODHA tidak merasa didiskriminasi yang nantinya dapat bedampak positif bagi kesehatannya serta penyesuaian dirinya.

\section{Simpulan}

Berdasarkan hasil penelitian diperoleh hasil bahwa dukungan sosial tidak memiliki hubungan dengan penyesuaian diri, sehingga dukungan sosial yang telah didapatkan oleh ODHA belum mampu membuat ODHA bisa melakukan penyesuaian diri dengan mudah.

\section{Daftar Pustaka}

Agustanti, (2010). "Hubungan antara Dukungan Sosial Terhadap Kualitas Hidup ODHA yang Tergabung di LSM Sakurai Support Group di Lampung". Thesis.

Azwar, S. 2003. Penyusunan Skala Psikologi. Yogyakarta: Pustaka Pelajar Offset. 
Philantrophy Journal of Psychology

2017, Vol 1 Nomor 1 17-25

Calhoun, J.F. dan Acocella, J.R. 1995. Psikologi Tentang Penyesuaian dan Hubungan Kemanusiaan. New York: Mc Graw Hill.

Chaplin, C.B. 1995. Kamus Lengkap Psikologi. (Terjemahan: Kartini Kartono).ed 1. cetakan ke-2. Jakarta: Grafindo Persada.

Davidoff. 1991. Psikologi Suatu Pengantar. Jilid 2. Alih Bahasa: Mari Jumiati. Jakarta: Erlangga.

Gerungan, W.A. 1996. Psikologi Sosial. Bandung: PT Eresco.

Hurlock, E. 2004. Psikologi Perkembangan. Jakarta: Erlangga Press.

Hutabarat, D.B. 2004. "Penyesuaian Diri Perempuan Pekerja Seks dalam Kehidupan Sehari-hari”. Arkhe (Jurnal Ilmiah Psikologi). Volume 9. Nomor 2. Halaman 70-81.

Kementrian Kesehatan RI. 2012: MEDIAKOM Mengenal, Mencegah Pertumbuhan HIV-AIDS. Jakarta.

Komisi Penanggulangan AIDS (KPA). 2003. Strategi Nasional Penanggulangan AIDS, 2003-2007, Menkosesra, KPAN, Jakarta.

Sarafino. 1998. Health Psikologi: Biopsychosocial Interaction. USA: John Willey and sons.

Smet, B. 1994, Psikologi Kesehatan. Jakarta: PT Grasindo. 